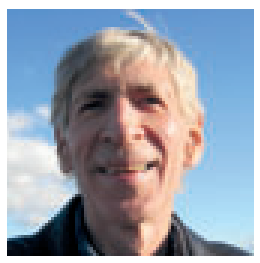

\title{
En god nyhet - og en dårlig
}

\author{
Psykiske problemer, i hvert fall av \\ mild eller moderat grad, går ikke \\ sjelden over. Men hvordan påvirker \\ behandling - farmakologisk, psyko- \\ terapeutisk eller annen form for \\ terapi - dette forløpet?
}

Folk venter seg mye av helsevesenet. Ikke bare skal det kurere sykdommer, lege skader og utsette slutten på livet, det skal også sørge for maksimal livskvalitet til siste stund. Forventningene er ikke mindre til det psykiske helsevernet. Sorg, skuffelser, kriser i arbeidsliv og familie - alt sammen er noe det psykiske helsevernet forventes å bidra til å takle. Personlige problemer og indre konflikter skal løses opp, melankoli og livsangst skal helbredes. Ja, ikke bare skal det onde fordrives, det gode skal også introduseres, gjennom positiv tenkning og liknende. Forventningene hos publikum hilses velkommen av ivrige talspersoner for profesjoner innenfor det psykiske helsevernet, og man forenes i kravet om mer ressurser. Dette er vel og bra, men av og til får man inntrykk av at om bare flere ressurser ble tilført helsevernet, vil alt bli fryd og gammen. I motsatt fall vil elendigheten rå.

Er dette riktig? Oppfølging av mennesker som er eller har vært $\mathrm{i}$ behandling viser at deres psykiske problemer blir mindre, og for en del forsvinner problemene helt. En skikkelig behandlingsstudie skal jo ha kontrollgruppe. De som utgjør kontrollgruppen, enten ved å stå på venteliste for behandling eller ved å få placebomedisin, blir også gjerne bedre. Placebo er et stort felt jeg ikke skal komme inn på. At de som må vente på behandling også blir bedre, skyldes nok at behandling søkes når ting er på det verste, og da kan det bare gå én vei for de flestemot bedring. Behandlingsstudier som sendes til publisering og aksepteres viser stort sett at det går aller best med dem som behandles, i hvert fall på kort sikt (i dag må imidlertid alle funn registreres, også de negative). Så da skulle vel alt være såre vel, behandling hjelper? Kanskje, eller...

I det siste er det blitt gjennomført en del studier hvor den psykiske helsen til store, alminnelige befolkningsgrupper er blitt fulgt gjennom flere år. Blant disse er det ikke så få som i starten har psykiske problemer av samme omfang som dem som deltar i behandlingsstudier. Psykiske problemer er vanlig blant folk flest. I oppfølgingstiden vil noen av disse søke og også få behandling for sine problemer, andre ikke. De som får behandling, har gjerne i starten større problemer, mindre ressurser og mindre støtte $i$ sine omgivelser. Men en god del mennesker med alvorlige problemer og lite støtte søker ikke eller får ikke behandling. Det er ingen sak å konstruere to grupper med like mye psykiske problemer som er like belastet i utgangspunktet, men hvor den ene gruppen mottar behandling, den andre ikke. Hvordan går det så med disse to gruppene? Jo, det besynderlige er at det går like bra eller bedre med dem som ikke får behandling!

Merkelig nok blir slike funn aldri eller sjelden diskutert i den vitenskapelige litteratur, ikke engang $i$ artiklene der funnene blir gjort kjent. Tvert imot konsentrerer forfatterne av slike artikler seg om andre resultater fra befolkningsstudien. Det hele nevnes bare i en kort setning i forbindelse med at man kontrollerer for hendelsen «behandling» om nødvendig. Man forstår tilbakeholdenheten. Dette er jo nedslående lesning for deres kolleger innen psykisk helsevern.

Ett forbehold må tas - i disse studiene er det inkludert få personer med alvorlige psykotiske tilstander. Og man kan møte studiene med en rekke innvendinger: utilstrekkelig grundig diagnostisering, brist i logikken (saken snus på hodet: rask bedring utelukker behandlingssøken heller enn omvendt), utilstrekkelig evaluering av ressurser i miljøet ved starten eller for sparsom registrering av positive og negative hendelser i oppfølgingstiden osv. Jeg tror at $i$ hvert fall en del av disse innvendingene kan imøtegås og at resultatene har sin gyldighet. Jeg tror også at liknende funn kan gjøres innenfor enkelte andre deler av helsevesenet hvor man møter kroniske, sykliske og episodiske sykdommer man bare delvis forstår årsaken til og hvor effektive behandlingsmåter ennå ikke er utviklet.

Studiene er en god nyhet for dem som har problemer. De går over for de fleste. Samtidig, og det må vi aldri glemme, er det en del mennesker problemene ikke forsvinner for. Men det er en dårlig nyhet for oss som er knyttet til det psykiske helsevernet. Vi synes ikke å makte å kurere i sterkere grad enn hva livet selv gjør. Jeg tror vi må ta to forhold innover oss. Psykisk helsevern er et ungt fag hvor avgrensningen av hva som egner seg for behandling og forståelsen av de psykiske problemenes natur og deres eliminering fremdeles er i sin spede begynnelse. Samtidig er menneskets evne til selvhelbredelse og det omgivende miljøs legende potensial stort og i høy grad fremdeles ukjent. Dessuten - dette betyr ikke at folk med psykiske problemer skal avvises av helsevesenet. De har like stor rett til kontakt med helsevesenet som andre med kroniske, sykliske, episodiske somatiske plager hvor forløpet påvirkes lite av kjent medisinsk behandling. Det dreier seg ikke bare om å kurere, men også om å lindre og trøste. $\mathrm{Og}$ - notabene - ikke skade. Min erfaring er at helsearbeidere ute i felten tar slike resultater fra befolkningsstudier med robust humør. Så får vi håpe at også de mest behandlingsivrige representanter for profesjonene gjør det.

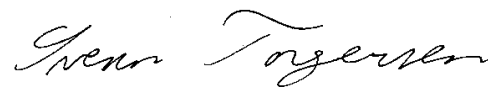

\section{I neste nummer:}

\author{
Akutte korsryggssmerter \\ Bildediagnostikk \\ ved vond rygg og nakke \\ Forskrivning av p-piller
}

\author{
Prioriteringsprosesser \\ Pleiere i akuttmedisinske team \\ Ultrasonografi \\ ved inflammatorisk tarm
}

